\title{
Potensi Perdagangan Komoditas Lada dari Indonesia ke Vietnam sebagai Salah SatuPasar Non-Tradisional
}

\author{
The Potency of Indonesia-Vietnam Pepper Commodity Trade as One of the Non-Traditional \\ Markets
}

\author{
Fathya Dhiya Ulhaq ${ }^{1}$, Ana Himatul Wahidah ${ }^{2}$, Usi Uswatun Hasanah ${ }^{3}$, \\ Melisa Indri Hartanti ${ }^{4}$, Arifah Fajrina $^{5}$
}

Departemen Ilmu Ekonomi,Fakultas Ekonomi dan Manajemen, Institut Pertanian Bogor

Jalan Agatis, Kampus Dramaga, Bogor 16680, Indonesia

Korespondensi: fathya_dhiya@apps.ipb.ac.id

[diterima: Maret 2021- revisi: April 2021-diterbitkan daring: Juli 2021]

\begin{abstract}
ABSTRAK
Kecenderungan perlambatan permintaan ekspor dari negara tujuan ekspor utama Indonesia saat ini menuntut Indonesia untuk diversifikasi ekspor ke negara lain. Vietnam merupakan negara yang berpotensi sebagai negara tujuan diversifikasi ekspor. Produk yang paling berpotensi untuk dimanfaatkan dalam diversifikasi ekspor ini ialah lada. Penelitian ini bertujuan untuk menganalisis potensi dan daya saing ekspor komoditas lada di pasar Vietnam; dan menganalisis hambatan tarif serta non-tarif ekspor lada ke pasar Vietnam. Data yang digunakan dalam penelitian ini adalah data time series tahun 2010-2019 yang bersumber dari United Nations of Commodity Trade Database (UN-Comtrade) dan World Integrated Trade Solution (WITS). Metode analisis data yang digunakan adalah ISP, IIT, RCA, EPD, X-Model, serta FI dan CR. Hasil penelitian menunjukkan bahwa integrasi perdagangan antara Indonesia dan Vietnam masih sangat lemah (IIT), daya saing komoditi lada Indonesia masih rendah jika dibandingkan dengan negara lain di pasar Vietnam (EPD), dan ekspor lada Indonesia ke Vietnam terdampak Non-Tariff Measure/NTM (FI dan CR). Meskipun, komoditas lada Indonesia di pasar Vietnam merupakan komoditas yang paling unggul (ISP), sangat potensial (RCA), dan memiliki daya saing yang cukup tinggi (X-Model). Maka dari itu, upaya yang direkomendasikan pada pemerintah adalah peningkatan kerja sama perdagangan dunia; pembenahan internal melalui pembentukan kelembagaan petani lada, melakukan diversifikasi produk, serta meningkatkan kualitas lada; dan memperhatikan pengawasan terhadap aspek Quality Control lada.
\end{abstract}

Kata kunci : Diversifikasi Ekspor, EPD, IIT, ISP, RCA

\section{ABSTRACT}

The trend of slowing export demand from Indonesia's main export destination countries currently requires Indonesia to diversify its exports to other countries. Vietnam is a country that has the potential as a destination for export diversification. The most potential product to be utilized in this export diversification is pepper. This study aims to analyze the potential and competitiveness of pepper exports in the Vietnamese market; as well as analyze tariff and non-tariff barriers to pepper exports to the Vietnamese market. The data used in this study are time series data for 2010-2019 sourced from the United Nations of Commodity Trade Database (UN-Comtrade) and the World Integrated Trade Solution (WITS). The analysis will be carried out through the analysis of ISP, IIT, RCA, EPD, as well as FI and CR. As for the results of this study, trade integration between Indonesia and Vietnam is still very weak(IIT), the competitiveness of Indonesia's pepper commodity is still low when compared to other countries in the Vietnam market (EPD), and Indonesia's pepper exports to Vietnam are affected by NonTariff Measure/NTM (FI and CR). Although, the Indonesian pepper commodity in the Vietnamese market is the most superior commodity (ISP), has great potential (RCA), and has a fairly high competitiveness (X-Model). Therefore, the recommended policy of the government is to increase world trade cooperation; internal improvements through the establishment of pepper farmer institutions, product diversification, and improving pepper quality; as well as pay attention to the supervision of aspects of Quality Control of pepper.

Keywords: Export Diversification, EPD, IIT, ISP, RCA

JEL classification: B22, F62, J11,

55 | Juli 2021

*Coresponding author:

E-mail: fathya_dhiya@apps.ipb.ac.id 


\section{PENDAHULUAN}

Perdagangan Internasional saat ini telah menunjukkan eksistensinya dengan begitu baik sehingga memberikan sumbangsih yang cukup besar terhadap perekonomian global. Semakin terbukanya suatu negara dalam proses perdagangan bebas (perdagangan internasional), dapat semakin membuka peluang ekspor suatu komoditi ke negara lain yang secara tidak langsung akan meningkatkan PDB negara yang bersangkutan. Di Indonesia, eksistensi perdagangan internasional, terutama pada sisi ekspor, didominasi oleh sektor non-migas. Data Kemendag (2019) menunjukkan bahwa 88\% komponen ekspor Indonesia ditopang oleh sektor non-migas. Selain itu, data WITS (2019) juga menunjukkan bahwa dari tahun 2016 hingga 2018 kontribusi nilai ekspor non-migas rata-rata sebesar $90 \%$ terhadap total ekspor Indonesia. Adapun komoditas dari sektor non-migas yang cukup berperan dalam perekonomian Indonesia adalah hasil pertanian. Peran sektor pertanian dalam perekonomian Indonesia masih tergolong signifikan, terutama bila dilihat dari beberapa indikator makroekonomi seperti Produk Domestik Bruto (PDB), pertumbuhan ekonomi, kesempatan kerja dan ekspor. Kementerian Pertanian (2019) mencatat, dari sisi pembentukan PDB, pada tahun 2017 sektor pertanian memberikan kontribusi sebesar $13.15 \%$ ( $R p$ 1,257,875,5 milyar), yang pada tahun 2019 triwulan ketiga mengalami peningkatan menjadi $13.45 \%$ (Rp 370,608,2 milyar). Sebagai penyumbang nilai tambah terhadap PDB, sektor pertanian menjadi kontributor kedua terbesar setelah sektor industri pengolahan yang pada kurun waktu tersebut memberikan sumbangsih sebesar 19 hingga 20\% terhadap PDB nasional. Apabila dilihat dari sisi penciptaan kesempatan kerja, sektor pertanian menjadi sektor utama dalam memberikan lapangan kerja di Indonesia. Kesempatan kerja di Indonesia mencatat bahwa selama tahun 2019 sektor pertanian menyerap tenaga kerja sebanyak $34,577,831$ orang (Kementan, 2019). Namun, dalam penelitian Harahap (2020), diketahui bahwa sasaran pasar ekspor non-migas Indonesia masih terfokus hanya ke negara-negara tertentu, antara lain China, Jepang, India, Amerika, Singapura, Uni Eropa, Malaysia, dan Korea Selatan. Dalam penelitiannya pun ia menambahkan bahwa terdapat kecenderungan negara-negara ekspor tujuan tersebut mengalami perlambatan terhadap permintaan impor dari Indonesia yang akan berdampak pula bagi perekonomian Indonesia. Oleh sebab itu, Indonesia perlu mulai fokus melakukan diversifikasi ekspor kepada negara diluar negaranegara tujuan ekspor utama yang selanjutnya disebut sebagai negara non-tradisional.

Salah satu bentuk kerja sama ekonomi dalam sektor perdagangan dituangkan melalui kawasan perdagangan bebas ASEAN atau yang lebih dikenal dengan ASEAN Free Trade Area (AFTA). Tujuan utama dari penerapan konsep AFTA adalah untuk meningkatkan volume perdagangan diantara sesama negara anggota. Indonesia dan Vietnam merupakan dua dari sepuluh negara yang tergabung ke dalam organisasi ASEAN (Perhimpunan Negara-Negara Asia Tenggara). Sebagai negara anggota, baik Indonesia maupun Vietnam turut berperan aktif dalam menyukseskan program-program yang menjadi tujuan pembangunan ASEAN yang dituangkan dalam berbagai bidang. Hubungan Indonesia dan Vietnam pun juga sudah terjalin cukup lama dan semakin diperkuat sejak ditandatanganinya perjanjian ekstradisi antara keduanya pada tanggal 27 Juni 2013 yang disahkan ke dalam Undang-Undang Republik Indonesia Nomor 5 Tahun 2015 tentang Pengesahan Perjanjian Ekstradisi antara Republik Indonesia dan Vietnam (Setiadi, 2016). Jauh sebelum perjanjian tersebut, hubungan bilateral Indonesia dan Vietnam terbilang cukup baik salah satunya dalam bidang ekonomi yang meliputi perdagangan internasional. Hubungan perdagangan antara Indonesia-Vietnam dapat dilihat pada tabel 1 . 
Tabel 1. Neraca Perdagangan Indonesia dengan Vietnam

\begin{tabular}{crrrrr}
\hline Uraian & \multicolumn{1}{c}{$\mathbf{2 0 1 6}$} & \multicolumn{1}{c}{$\mathbf{2 0 1 7}$} & \multicolumn{1}{c}{$\mathbf{2 0 1 8}$} & \multicolumn{1}{c}{$\mathbf{2 0 1 9}$} & \multicolumn{1}{c}{$\mathbf{2 0 2 0}$} \\
\hline Total perdagangan & $6,274,043.9$ & $6,815,667.1$ & $8,376,482.0$ & $9,001,554.2$ & $8,071,607.6$ \\
Migas & $67,296.1$ & $11,923.6$ & $36,604.1$ & $58,974.8$ & $27,084.1$ \\
Non migas & $6,206,747.7$ & $6,803,743.4$ & $8,339,877.9$ & $8,942,579.4$ & $8,044,523.6$ \\
\hline Sumber: Kemendag, 2016-2020 & & & &
\end{tabular}

Tabel 2. Komoditas Pertanian Unggulan Ekspor Indonesia-Vietnam

\begin{tabular}{cccccc}
\hline Tahun & Palm Oil & Molluscs & Bread & Coconuts & Pepper \\
\hline 2015 & 83688.8 & 32722.57 & 58784.78 & 96104.18 & 179912.3 \\
2016 & 122114 & 61323.09 & 75754.82 & 87893.28 & 122435.1 \\
2017 & 121318.8 & 54819.64 & 81517.87 & 86356.47 & 68111.45 \\
2018 & 259841.3 & 74958.92 & 88003.95 & 69054.93 & 56569.5 \\
2019 & 183725.3 & 109542.6 & 89572.15 & 88386.02 & 46611.38 \\
\hline
\end{tabular}

Sumber : UN COMTRADE (diolah), 2019

Tabel 2 menunjukkan lima komoditas pertanian Indonesia yang memiliki volume ekspor terbanyak di pasar Vietnam. Salah satu komoditas pertanian adalah lada. Dibandingkan dengan komoditas pertanian unggulan lainnya, pepper atau lada memiliki nilai daya saing yang potensial di pasar Indonesia-Vietnam. Artinya, komoditas pepper atau lada dapat menjadi komoditas unggulan Indonesia di Vietnam dan pasar tradisional lainnya. Hal ini diantaranya dikarenakan lada Indonesia memiliki tingkat produksi yang cukup tinggi. Selain itu, iklim dan lahan yang tersedia untuk perkembangan lada di Indonesia cukup potensial untuk pertumbuhan komoditas lada. Indonesia juga menjadi salah satu negara yang terkenal dengan produksi rempahrempahnya, termasuk lada. Komoditas lada, pada zaman penjajahan pernah menarik bangsa asing untuk memonopoli sumber daya alam yang menjadi kekayaan bangsa Indonesia. Dengan nilai tambah cerita sejarah tersebut, semakin menjadikan komoditas lada sebagai komoditas unggulan Indonesia yang berpotensi untuk dikembangkan dan diproduksi.

Tabel 3. Lima Negara Eksportir Lada Terbesar ke Vietnam Tahun 2019

\begin{tabular}{rccc}
\hline No & Negara & Nilai Ekspor (1000 USD) & Persentase (\%) \\
\hline 1. & Indonesia & 46611378 & 43.55 \\
2. & Brazil & 29348121 & 27.42 \\
3. & India & 17570927 & 16.42 \\
4. & China & 4964532 & 4.64 \\
5. & Kamboja & 3429731 & 3.20 \\
\hline
\end{tabular}

Sumber: UN COMTRADE (diolah), 2019 
Tabel 3 menjelaskan tentang empat negara eksportir lada terbesar ke Vietnam yang didominasi oleh negara kawasan Asia, diantaranya Indonesia, India, China, dan Kamboja. Indonesia merupakan salah satu dari eksportir lada terbesar dengan area penanaman lada Indonesia tersebar di beberapa pulau, seperti Sumatera, Jawa, Kalimantan, dan Sulawesi (Ariesha, 2017). Hal ini menciptakan kestabilan iklim perekonomian lada Indonesia yang sangat tergantung pada kondisi pasar dunia. Apalagi saat ini perdagangan sudah mulai memasuki era global yang semakin memudahkan. Pada tahun 2019, eksportir utama lada adalah Indonesia, Brazil, India, China, dan Kamboja. Pada tahun tersebut Indonesia memiliki kontribusi ekspor ke negara tujuannya di dunia sebesar $43.55 \%$ dari total nilai ekspor lada dunia yang masih menjadi primadona dan mengungguli negara-negara pesaingnya. Lada Indonesia menjadi salah satu komoditas unggulan dan aktivitas ekspornya menjadi potensi Indonesia dalam mengembangkan perekonomiannya dan memperoleh keuntungan. Pada zaman yang semakin global ini, lada akan semakin banyak digunakan pada industri makanan sebagai bumbu dan bahan penyedap yangalami (Aerisha, 2017).

Seperti yang disampaikan oleh Departemen Pertanian, Indonesia dijuluki sebagai produsen utama lada di dunia, terutama lada hitam (Lampung Black Pepper) yang dihasilkan di Lampung dan lada putih (Muntok White Pepper) yang dihasilkan di Kepulauan Bangka Belitung. Kedua jenis ini digunakan sebagai standar perdagangan lada dunia. Persaingan antara negara produsen lada di ASEAN menjelaskan bahwa keunggulan komparatif akan terus terjadi di setiap sektor perekonomian suatu negara, untuk melihat apakah negara tersebut masih memiliki daya saing dengan negara lain. Beberapa penelitian terkait daya saing lada sudah dilakukan beberapa peneliti di Indonesia. Namun, negara tujuan ekspor dalam penelitian- penelitian sebelumnya berbeda dengan yang dilakukan dalam penelitian ini yaitu negara Vietnam. Sedangkan dalam hal metode, penelitian sebelumnya tidak melakukan analisis hambatan tarif dan non tarif. Sepertistudi yang dilakukan Jusuf dan Setyari (2020) yang menyebutkan bahwa nilai RCA Komoditas lada Indonesia di pasar ASEAN berada diatas nol yang berarti Indonesia memiliki keunggulan komparatif pada komoditas lada di pasar ASEAN. Selain itu, Nurhayati dkk (2018) melalui X-model juga menyebutkan bahwa Vietnam merupakan pasar potensial untuk mengembangkan komoditas lada.

Akan tetapi, harga yang ditawarkan Vietnam terhadap lada Indonesia hanya sebesar US\$ 4,425 ribu/ton lada dengan jumlah ekspor 11,173ton pada tahun 2017. Berbeda jauh dari penawaran yang diberikan oleh Amerika yaitu sebesar US\$ 7,765 ribu/ton yang justru hanya diekspor 2,607 pada tahun yang sama. Hal ini menjadi indikator masalah pada ekspor lada Indonesia yang tidak memiliki hambatan ekspor di pasar Vietnam, namun menjadi masalah di pasar Amerika. Salah satu penyebabnya adalah rendahnya mutu lada Indonesia yang disebabkan oleh kontaminasi mikroorganisme dikarenakan sistem produksi petani Indonesia yang masih tradisional (Balqis dan Yanuar 2021).

Oleh karena itu, berdasarkan latar belakang di atas, penelitian ini bertujuan untuk: 1) menganalisis potensi dan daya saing ekspor komoditas lada di pasar Vietnam; dan 2) menganalisis hambatan tarif dan non-tarif ekspor lada ke pasar Vietnam. Adapun hasil penelitian ini diharapkan bisa memberikan kontribusi bagi kebijakan pemerintah dalam meningkatkan daya saing komoditas lada terutama bagi negara non tujuan utama. Selain itu, penelitian ini diharapkan bisa memberikan rekomendasi bagi pemerintah dalam meningkatkan mutu dan kualitas lada Indonesia yang lebih baik untuk ekspor. 


\section{LANDASAN TEORI}

\section{Teori Perdagangan Internasional}

Perdagangan internasional merupakan cabang dari ekonomi internasional, merupakan perdagangan yang dilakukan oleh penduduk suatu negara dengan penduduk negara lain atas dasar kesepakatan bersama. Tiap negara yang melakukan perdagangan terbuka bertujuan mencari keuntungan dari perdagangan tersebut. selain dari motif keuntungan, Krugman (2003) menjelaskan bahwa alasan utama terjadinya perdagangan internasional adalah sebagai berikut:

1. Negara-negara berdagang karena mereka berbeda satu sama lain

2. Negara-negara melakukan perdagangan dengan tujuan untuk mencapai skala ekonomi (economic of scale)

Oleh karena itu, perdagangan internasional adalah sejumlah transaksi jual beli atau perdagangan antara negara satu dengan negara lainnya dalam bentuk ekspor dan impor, pada suatu pasar dikarenakan berbeda satu sama lain, untuk mencapai keuntungan yang maksimal bagi kedua belah pihak dan skala ekonomi.

\section{Teori Daya Saing}

\section{Keunggulan Absolut}

Teori keunggulan absolut atau teori murni perdagangan internasional di gagas oleh Adam Smith. Dasar teori ini yaitu suatu negara akan melakukan pertukaran apabila setiap negara mendapatkan keuntungan yang mutlak dari proses perdagangan. Suatu negara dikatakan memiliki keunggulan absolut apabila dapat memproduksi suatu barang dengan biaya yang lebih murah dibandingkan dengan negara lain. Negara yang memiliki keunggulan absolut akan melakukan spesialisasi dan akan mengekspor barang tersebut ke negara lain. Keunggulan absolut adalah suatu kondisi dimana penjual dapat memproduksi barang lebih efisien dibandingkan pesaingnya. Produksi yang efisien ini memungkinkan produsen mendapatkan keuntungan yang lebih besar dengan asumsi semua produknya habis terjual. Sedangkan bagi negara yang tidak memiliki keunggulan absolut akan mengimpor barang tersebut.

Adapun terdapat beberapa asumsi dari teori keunggulan absolut, yaitu:

1. Tenaga kerja merupakan satu-satunya faktor produksi yang digunakan

2. Barang yang diproduksi kedua negara memiliki kualitas yang sama

3. Pertukaran dilakukan secara barter

4. Tidak ada biaya transport

\section{Keunggulan Komparatif}

Meskipun suatu negara dinilai kurang efisien dibandingkan negara lain dalam memproduksi kedua barang, tetapi masih dapat melakukan pertukaran yang sama-sama menguntungkan kedua negara. David Ricardo menyatakan value atau harga dari suatu produk ditentukan oleh lamanya waktu yang diperlukan untuk memproduksinya. Secara singkat suatu negara akan mengekspor barang dengan produktivitas tenaga kerja yang tinggi dalam memproduksi suatu barang (relatif efisien) dan mengimpor barang dengan tenaga kerja yang produktivitasnya rendah. Kedua negara akan memperoleh keuntungan lewat dua pilihan yaitu dengan memproduksi dan menjual produk lain sebagai penukar untuk produk yang diinginkan atau perdagangan akan memperluas kemungkinan produk substitusi yang pada gilirannya dapat menciptakan keuntungan perdagangan.

Asumsi-asumsi yang digunakan dalam teori keunggulan komparatif, yaitu: 
1. Perdagangan hanya dilakukan oleh dua negara

2. Kedua negara melakukan perdagangan secara sukarela (bebas)

3. Hanya terdapat dua macam yang diperdagangkan

4. Tenaga kerja bersifat seragam (homogen)

5. Tenaga kerja bebas melakukan mobilitas di dalam suatu negara, tidak antar negara

6. Biaya produksi dianggap tetap (fixed cost)

7. Kualitas barang homogen

8. Tidak ada biaya transportasi

9. Teknologi tetap

\section{Hambatan Perdagangan Tarif dan Non- Tarif}

Jenis hambatan perdagangan yang paling penting menurut sejarah adalah tarif. Tarif merupakan pajak atau bea masuk yang dibebankan terhadap komoditas perdagangan yang memasuki suatu batas negara. Tarif impor merupakan bea masuk komoditas impor, sementara tarif ekspor adalah bea masuk komoditas ekspor. Negara-negara berkembang sangat bersandar pada tarif ekspor untuk meningkatkan penerimaan karena pungutan ringannya. Di sisi lain, negara-negara maju selalu membebankan tarif untuk melindungi beberapa industri, serta kebanyakan menggunakan pajak pendapatan untuk meningkatkan penerimaan. Terdapat tiga macam tarif yang biasa diterapkan negara-negara di dunia. Pertama, tarif ad valorem yaitu persentase tetap harga komoditas perdagangan. Kedua, tarif khusus yaitu jumlah tetap tiap satuan barang dari komoditas perdagangan. Terakhir, tarif gabungan yaitu kombinasi dari tarif khusus dan ad valorem. Adanya tarif akan mendorong inefisiensi yang disebut sebagai biaya proteksi atau kerugian masyarakat.

Meskipun menurut sejarah tarif merupakan jenis hambatan yang paling penting, terdapat berbagai jenis hambatan perdagangan lainnya, seperti kuota impor, pembatasan ekspor sukarela, dan kebijakan antidumping. Kuota impor merupakan hambatan kuantitatif langsung berupa jumlah komoditas yang diperbolehkan untuk diimpor atau diekspor. Kuota impor dapat digunakan untuk melindungi produksi dalam negeri, pertanian dalam negeri, dan/atau karena alasan neraca pembayaran. Pembatasan ekspor sukarela mengacu pada kasus di mana negara pengimpor membebani negara lainnya untuk mengurangi ekspor komoditas secara "sukarela", melalui serentetan ancaman perdagangan yang lebih berat, ketika ekspor tersebut mengancam seluruh industri dalam negeri. Ketika pembatasan ekspor sukarela berhasil, pembatasan tersebut memiliki seluruh pengaruh ekonomi dari kuota impor yang senilai, kecuali bahwa pembatasan tersebut diatur oleh negara pengekspor, dan juga pengaruh penerimaan atau sewa yang ditangkap oleh eksportir asing. Terakhir, hambatan perdagangan juga berasal dari dumping. Dumping merupakan ekspor komoditas di bawah biayanya atau setidaknya menjual komoditas dengan harga yang lebih rendah di luar negeri dibandingkan dengan di dalam negeri. Pembatasan perdagangan untuk mengatasi dumping dibenarkan dan diperbolehkan untuk melindungi industri dalam negeri dari persaingan tidak adil dengan luar negeri. Pembatasan tersebut biasanya dalam bentuk bea cukai antidumping untuk menanggung kerugian perbedaan harga, atau ancaman berupa pengenaan bea cukai semacam itu.

\section{Kondisi Perdagangan Antara Indonesia- Vietnam Menurut Penelitian Terdahulu}

Penelitian terkait perdagangan lada Indonesia-Vietnam sudah banyak dilakukan peneliti terdahulu. Jusuf dan Setyari (2020) telah membuktikan bahwa nilai RCA komoditas lada Indonesia di pasar ASEAN 
berada diatas nol yang berarti Indonesia memiliki keunggulan komparatif. Penelitian ini sejalan dengan penelitian Kurnianto dkk (2016) yang menyebutkan bahwa secara kompetitif lada Indonesia belum mempunyai daya saing yang kuat (periode 2010-2014) tetapi mempunyai daya saing secara komparatif yang sangat tinggi. Sehingga, dapat dikatakan bahwa lada Indonesia secara kualitas stagnan, akan tetapi perdagangan lada Indonesia terus dan tetap terjadi karena tingginya permintaan akan lada Indonesia di pasar internasional.

Selain itu, Nurhayati dkk (2018) juga melakukan penelitian yang sama menggunakan model RCA, secara keseluruhan lada Indonesia di sepuluh pasar utama yang memiliki keunggulan komparatif dan berdaya saing kuat, kecuali di pasar Malaysia, dan Vietnam merupakan salah satu pasar potensial untuk dilakukan perdagangan. Jannah dkk (2019) menyebutkan bahwa sebenarnya, Indonesia memiliki keunggulan kualitas lada dan luas tanam lada yang lebih baik dari Vietnam, akan tetapi keunggulan ini belum mampu dikembangkan secara maksimal sehingga produktivitas lada nasional masih rendah. Sehingga, jika hal ini dapat diperbaiki mengingat potensi daya saing dan permintaan komoditas lada yang masih tinggi, maka minat petani untuk meningkatkan produktivitas lada diharapkan akan semakin tinggit yang berdampak untuk meningkatkan nilai daya saing lada Indonesia.

\section{METODE}

\section{Jenis dan Sumber Data}

Data yang digunakan pada penelitian ini merupakan data sekunder kuantitatif. Jenis data yang digunakan adalah data panel yang terdiri dari data time series dengan periode tahunan selama sepuluh tahun (2010- 2019 dan data cross section dengan data yang digunakan ialah lima komoditas terbesar yang diekspor oleh Indonesia ke Vietnam. Data utama yang digunakan bersumber dari United Nations of Commodity Trade Database (UN-Comtrade) dan World Integrated Trade Solution (WITS). Kode HS dari komoditas lada yang diteliti adalah kode HS 0904. Adapun data pendukung yang digunakan bersumber dari Kementerian Perdagangan dan Kementerian Pertanian.

\section{Metode Analisis dan Pengolahan Data}

Metode analisis yang digunakan pada penelitian ini yaitu analisis ISP, IIT, RCA, EPD, serta FI dan CR.

1. Indeks Spesialisasi Perdagangan (ISP)

Indeks ISP digunakan untuk menganalisis posisi atau tahapan perkembangan suatu produk. ISP ini dapat menggambarkan apakah untuk suatu jenis produk, suatu negara cenderung menjadi negara eksportir atau importir. Suatu negara dikatakan sebagai eksportir jika nilai indeks ISP bernilai positif dan bertindak sebagai importir jika nilai indeks ISP bernilai negatif. Rumus untuk perhitungan indeks ISP yaitu :

$$
I S P=\frac{(\mathrm{Xia}-\mathrm{Mia})}{(\mathrm{Xia}+\mathrm{Mia})}
$$

Dimana:

$\mathrm{i}=$ komoditi

$\mathrm{a}=$ negara

\section{Intra Industry Trade Index (IIT Index)}

Indeks IIT digunakan untuk menganalisis tingkat integrasi dalam suatu kawasan tertentu. Integrasi yang tinggi menunjukkan kedekatan perdagangan diantara negara-negara di kawasan tersebut. Intra industry trade (IIT) index yang umum digunakan adalah Grubel-Lloyd Index dengan rumus:

$$
I I T=1-\frac{\sum \mathrm{I} X-M \mathrm{I}}{\sum \mathrm{I} X+M \mathrm{I}} \mathrm{X} 1
$$




\section{Dimana:}

Dimana:

$$
\begin{aligned}
\mathrm{X}= & \text { Nilai ekspor komoditi } \mathrm{i} \text { dari negara } \mathrm{j} \text { ke } \\
& \text { negara } \mathrm{k} \\
\mathrm{M}= & \begin{array}{l}
\text { Nilai impor komoditi } \mathrm{i} \text { dari negara } \mathrm{j} \mathrm{ke} \\
\text { negara } \mathrm{k}
\end{array}
\end{aligned}
$$

Nilai Grubel Lloyd index berkisar antara 0 sampai 100. Jika jumlah yang diekspor sama dengan jumlah yang diimpor untuk suatu produk, maka indeksnya akan bernilai 100. Sebaliknya apabila perdagangan suatu negara hanya melibatkan satu pihak saja (ekspor atau impor saja) maka nilai indeksnya adalah 0 .

\section{Revealed Comparative Advantage (RCA)}

Indeks RCA digunakan untuk mengukur keuntungan maupun kerugian relatif komoditi tertentu pada suatu negara yang tercermin pada pola perdagangannya, seperti pangsa pasar ekspor. Berdasarkan metode RCA, perdagangan antar wilayah sebenarnya menunjukkan keunggulan komparatif yang dimiliki oleh suatu wilayah. Variabel yang diukur pada metode ini meliputi kinerja ekspor suatu produk pada wilayah terhadap total ekspor wilayah tersebut yang kemudian dibandingkan dengan pangsa nilai produk dalam perdagangan dunia. Pada penelitian ini, metode RCA digunakan untuk mengukur posisi daya saing dan ekspor lada Indonesia di pasar Vietnam. Jika nilai RCA yang diperoleh bernilai lebih dari satu $(\mathrm{RCA}>1)$, hal tersebut berarti negara tersebut memiliki keunggulan komparatif diatas rata-rata dunia hingga komoditi tersebut memiliki daya saing yang kuat. Sedangkan jika nilai RCA yang diperoleh kurang dari satu (RCA <1), hal tersebut berarti bahwa negara tersebut memiliki keunggulan komparatif dibawah rata-rata dunia sehingga negara tersebut memiliki daya saing yang lemah pada komoditas tersebut. Adapun formula RCA tersebut adalah sebagai berikut :

$$
R C A=\frac{\frac{x_{i}}{x_{t}}}{\frac{w_{i}}{w_{t}}}
$$

$\mathrm{X}_{\mathrm{i}}=$ Nilai ekspor komoditi i dari negara $\mathrm{j}$ ke negara $\mathrm{k}$

$X_{t}=$ Nilai total ekspor Indonesia ke negara $j$

$\mathrm{W}_{\mathrm{i}}=$ Nilai ekspor komoditi i dunia

$\mathrm{W}_{\mathrm{t}}=$ Nilai total ekspor dunia

\section{Export Product Dynamics (EPD)}

Salah satu indikator yang dapat memberikan gambaran yang baik tentang tingkat daya saing adalah Export Product Dynamics (EPD). Indikator ini mengukur posisi pasar dari produk suatu negara untuk tujuan pasar tertentu. Ukuran ini mempunyai kemampuan untuk membandingkan kinerja ekspor di antara negara-negara di seluruh dunia. Selain itu, dengan menggunakan EPD dinamis atau tidaknya performa suatu produk dapat diketahui. Sebuah matriks EPD terdiri dari daya tarik pasar dan informasi kekuatan bisnis. Daya tarik pasar dihitung berdasarkan pertumbuhan dari permintaan sebuah produk untuk tujuan pasar tertentu, dimana informasi kekuatan bisnis diukur berdasarkan pertumbuhan dari perolehan pasar (market share) sebuah negara pada tujuan pasar tertentu. Kombinasi dari daya tarik pasar dan kekuatan bisnis ini menghasilkan karakter posisi dari produk yang ingin dianalisis ke dalam empat kategori. Keempat kategori itu adalah "Rising Star", "Falling Star", "Lost Opppotunity", dan "Retreat".

Adapun yang dimaksud dengan pangsa pasar ekspor suatu negara (negara i) dan pangsa pasar produk (produk $n$ ) dalam perdagangan dunia adalah sebagai berikut:

Sumbu X: pertumbuhan pangsa pasar ekspor i

$$
\frac{\Gamma_{t=1}^{t}\left(\frac{\Delta \iota h}{X}\right) t \times 100 \%-\sum_{t=1}\left(\frac{\Delta \iota n}{X n}\right) t-1 \times 100 \%}{T}
$$


Sumbu Y: pertumbuhan pasngsa pasar produk

$$
\frac{\sum_{t=1}^{t}\left(\frac{\Lambda \pi t}{X}\right) t \times 100 \%-\sum_{t=1}\left(\frac{\Lambda \pi t}{X}\right) t-1 \times 100 \%}{T}
$$

Posisi pasar yang ideal adalah yang mempunyai pangsa pasar tertinggi pada ekspornya sebagai "Rising Star" atau "bintang terang", yang menunjukkan bahwa negara tersebut memperoleh tambahan pangsa pasar pada produk mereka yang bertumbuh cepat (fast-growing products). "Lost Opportunity" atau "kesempatan yang hilang", terkait dengan penurunan pangsa pasar pada produk- produk yang dinamis, adalah yang posisi yang paling tidak diinginkan. "Falling Star" atau "bintang jatuh" juga tidak disukai, meskipun masih lebih baik jika dibandingkan dengan "Lost Opportunity", karena pangsa pasarnya tetap meningkat. Sementara itu, "Retreat" atau "kemunduran" biasanya tidak diinginkan, tetapi pada kasus tertentu 'mungkin' diinginkan jika pergerakannya menjauhi produkproduk yang stagnan dan menuju produk-produk yang dinamik (Bappenas, 2009).

\section{FI dan CR}

FI dan CR dilakukan untuk melihat hambatan non-tarif yang diberlakukan suatu negara dalam mengimpor sesuatu. FI akan mengukur share dari HS6 yg terkena setidaknya satu hambatan nontarif. Jika nilai FI suatu negara bernilai $100 \%$, berarti semua produk di kelompok tersebut setidaknya terkena 1 jenis NTM. Artinya, ada hal-hal yang masih harus diperhatikan negara tersebut dalam mengekspor ke negara partner seperti, food safety dan kebersihan. Nilai CR mengukur seberapa besar produk yang diekspor terdampak akibat adanya penerapan hambatan non-tarif oleh suatu negara partner perdagangan (importir).

\section{HASIL DAN PEMBAHASAN}

\section{Potensi Lada Sebagai Komoditas Ekspor Indonesia ke Vietnam}

Lada merupakan komoditas ekspor Indonesia yang paling unggul diantara komoditas pertanian lain. Berdasarkan hasil analisis ISP (Indeks Spesialisasi Perdagangan) antara perdagangan dari komoditas lada negara Indonesia dan Vietnam, negara Indonesia memiliki daya saing yang kuat terhadap komoditas lada atau berpotensi sebagai negara eksportir. Hal tersebut ditunjukkan dari nilai ISP yang selalu positif setiap tahunnya dari tahun 2010-2019 seperti yang tercantum pada tabel 4 Secara global, komoditas lada Indonesia di pasar internasional berada di posisi kedua dengan daya saing tinggi setelah Brazil sebagai negara eksportir lada. Indonesia memiliki peluang menyaingi Brazil dengan memaksimalkan produksi lada dalam negeri (Kurnianto dkk 2016).

Tabel 4. Analisis ISP Ekspor Produk Lada Indonesia ke Vietnam Tahun 2010-2019

\begin{tabular}{ccc}
\hline Tahun & Kode HS & ISP \\
\hline 2010 & 0904 & 0.952414525 \\
2011 & 0904 & 0.772238764 \\
2012 & 0904 & 0.941158723 \\
2013 & 0904 & 0.965189578 \\
2014 & 0904 & 0.027283987 \\
2015 & 0904 & 0.920115849 \\
2016 & 0904 & 0.782830213 \\
2017 & 0904 & 0.911796426 \\
2018 & 0904 & 0.947132926 \\
2019 & 0904 & 0.967335597
\end{tabular}

Sumber: WITS (diolah), 2020 
Komoditas lada semakin berpotensi sebagai produk utama ekspor ke Vietnam ditunjukkan dari hasil analisis Revealed Comparative Advantage (RCA). Analisis ini digunakan untuk mengukur sejauh mana daya saing suatu produk pada perdagangan antarnegara, dalam hal ini Indonesia dengan Vietnam. Hasil RCA dari ekspor komoditas lada ke Vietnam menunjukkan nilai RCA yang selalu lebih dari 1 setiap tahunnya seperti terlihat pada tabel 5 Nilai RCA tersebut mengindikasikan bahwa daya saing komoditas lada Indonesia memiliki daya saing yang kuat di pasar Vietnam, sehingga semakin

menunjukkan bahwa komoditas lada memang komoditas yang sangat potensial untuk peningkatan kegiatan perdagangan Indonesia ke Vietnam. Temuan ini sejalan dengan penelitian terdahulu yang dilakukan Jannah dkk (2019), secara keseluruhan lada Indonesia di sepuluh pasar utama yang memiliki keunggulan komparatif dan berdaya saing kuat, kecuali di pasar Malaysia.

Tabel 5. Hasil Perhitungan RCA Ekspor Lada Indonesia ke Vietnam Tahun 2010-2019

\begin{tabular}{ccc}
\hline Tahun & Kode HS & Indeks RCA \\
\hline 2010 & 0904 & 30.68057194 \\
2011 & 0904 & 20.12375437 \\
2012 & 0904 & 30.3879125 \\
2013 & 0904 & 35.12944389 \\
2014 & 0904 & 17.46366133 \\
2015 & 0904 & 33.16189984 \\
2016 & 0904 & 26.08406034 \\
2017 & 0904 & 12.01517067 \\
2018 & 0904 & 10.6229922 \\
2019 & 0904 & 22.97671501 \\
\hline
\end{tabular}

Sumber: WITS (diolah), 2020

Indonesia memiliki sumber daya alam yang melimpah, iklim dan lahan yang cukup potensial untuk mendukung pertumbuhan komoditas lada. Akan tetapi potensi ini belum dimanfaatkan secara maksimal sehingga produktivitas lada nasional masih tergolong rendah. Padahal, produktivitas sangat mempengaruhi kemampuan negara untuk melakukan ekspor. Apabila produktivitas tinggi maka kemampuan ekspor pun akan tinggi. Selain itu, kualitas serta diversifikasi produk perlu diperhatikan guna meningkatkan nilai tambah lada Indonesia. Pemerintah perlu membuat kebijakan yang terintegrasi dari hulu dan hilir seperti peningkatan kualitas benih dan produksi, perlindungan terhadap hama, perbaikan industri pengolahan yang disertai dengan peningkatan kualitas, efisiensi biaya produksi serta meningkatkan kerja sama diplomatik baik bilateral, regional dan multilateral (Azahari dkk 2021).

Kerja sama perdagangan dengan negara lain penting dilakukan untuk mempercepat dan mempromosikan komoditas yang dimiliki sehingga membuka peluang pasar baru untuk produk tersebut. Adanya peningkatan pasar suatu komoditas berdampak juga terhadap penguasaan pangsa pasar komoditas Indonesia tersebut di pasar internasional. Berdasarkan analisis yang dilakukan, integrasi perdagangan antara Indonesia dan Vietnam masih sangat lemah, meskipun sempat menguat pada tahun 2014. 
Hal ini ditunjukkan dari hasil analisis Intra Industry Trade (IIT) seperti terlihat pada tabel 6 Analisis IIT digunakan untuk menganalisis tingkat integrasi dalam suatu kawasan tertentu. Integrasi yang lemah pada perdagangan komoditas lada antara Indonesia dengan Vietnam dikarenakan Vietnam bukan negara tujuan utama ekspor Indonesia atau termasuk kategori negara non-tradisional. Hal tersebut disebabkan karena kontribusi dari ekspor negara Vietnam masih sedikit terhadap Indonesia.

Tabel 6. Hasil Indeks IIT Ekspor Lada Indonesia ke Vietnam Tahun 2010-2019

\begin{tabular}{ccc}
\hline Tahun & Kode HS & IIT index \\
\hline 2010 & 0904 & 4.758547542 \\
2011 & 0904 & 22.77612361 \\
2012 & 0904 & 5.884127738 \\
2013 & 0904 & 3.481042156 \\
2014 & 0904 & 97.27160134 \\
2015 & 0904 & 7.988415073 \\
2016 & 0904 & 21.71697874 \\
2017 & 0904 & 8.820357407 \\
2018 & 0904 & 5.286707375 \\
\hline 2019 & 0904 & 3.266440273
\end{tabular}

Sumber: WITS (diolah), 2020

Rendahnya nilai integrasi perdagangan Indonesia dengan mitra dagangnya dikarenakan masing- masing negara memiliki keunggulan komparatif pada komoditas lada sehingga setiap negara mitra dagang bisa dikatakan tidak terlalu sering melakukan perdagangan intra-industri satu sama lain (Jusuf dan Setyari 2020). Oleh sebab itu, integrasi perdagangan ekspor komoditas lada antara Indonesia ke Vietnam perlu ditingkatkan lagi mengingat komoditas lada merupakan komoditas yang sangat potensial untuk diekspor ke pasar Vietnam. Selain integrasi yang masih lemah, posisi ekspor komoditas lada Indonesia ke Vietnam pun masih perlu ditingkatkan. Pasalnya, posisi ekspor di Indonesia di pasar Vietnam sangat berfluktuasi setiap tahunnya cenderung kurang potensial. Hal ini terlihat dari hasil analisis EPD yang tercantum pada tabel 7 .

Tabel 7. Hasil Perhitungan EPD Ekspor Lada Indonesia ke Vietnam Tahun 2020-2019

\begin{tabular}{cccc}
\hline Tahun & $\begin{array}{c}\text { Pertumbuhan Pangsa } \\
\text { Pasar Produk (\%) }\end{array}$ & $\begin{array}{c}\text { Pertumbuhan Pangsa } \\
\text { Pasar Ekspor }(\%)\end{array}$ & Posisi Pasar \\
\hline 2010 & $\mathrm{Na}$ & $\mathrm{Na}$ & - \\
2011 & $-3,739,464,325$ & $-455,219,654$ & Retreat \\
2012 & $3,438,205,161$ & $-1,100,831,959$ & Falling Star \\
2013 & $-2,141,547,267$ & $-1,534,981,002$ & Retreat \\
2014 & $-555,598,385$ & $-1,060,533,466$ & Retreat \\
2015 & $9,688,385,794$ & $3,682,630,762$ & Rising Star \\
2016 & $-1,606,641,472$ & $6,708,737,495$ & Lost Opportunity \\
2017 & $-5,455,586,686$ & $-1,344,097,119$ & Retreat \\
2018 & $3,849,228,793$ & $1,745,901,577$ & Rising Star \\
2019 & $1,325,108,643$ & $7,498,443,377$ & Rising Star \\
\hline Rata-rata & 11,32307689 & $-0,8345478363$ & Falling Star \\
\hline
\end{tabular}

Sumber: WITS (diolah), 2020 
Pada tabel 8, terlihat bahwa komoditas lada Indonesia memiliki rata-rata nilai EPD yaitu 0.83 Sehingga dapat disimpulkan bahwa komoditas lada Indonesia berada pada posisi falling star, yaitu pangsa pasar tetap meningkat meskipun pergerakan produk pada pasar global terjadi penurunan. Maka dalam hal ini, daya saing komoditi lada Indonesia masih rendah jika dibandingkan dengan negara lain di pasar Vietnam. Kondisi internal komoditi lada Indonesia memiliki keunggulan kompetitif pada faktor sumber daya alam. Pada faktor sumber daya manusia, ketersediaan dan peran sumber daya manusianya cukup mendukung tetapi terdapat kekurangan dalam hal kualitas tenaga kerja terutama dalam pemanfaatan dan penerapan IPTEK serta bibit unggul yang belum maksimal. Selain itu, kondisi infrastruktur belum sepenuhnya memadai terutama sarana dan prasarana pembenihan.
Kekurangan juga terdapat pada kondisi permodalan yang terbatas yang dapat dilihat dari masih kurangnya peran lembaga permodalan yang mau mendukung pengembangan pengusahaan lada. Dari sisi permintaan, komoditi lada Indonesia dapat memenuhi kebutuhan domestik dan konsumsi luar negeri. Komoditi lada Indonesia masih mempunyai kelemahan dari sisi industri terkait dan pendukung yang ditandai dengan belum adanya industri penangkar benih/bibit dan belum majunya industri olahan lada. Selain komoditas lada, empat komoditas unggulan lain yang juga dapat menjadi komoditas unggulan ekspor Indonesia ke Vietnam antara lain: Minyak kelapa sawit, Moluska, Roti dan pastry, serta kelapa dan kacang-kacangan. Dari keempat produk lainnya, terlihat dalam analisis X-Model bahwa komoditas lada lah yang paling unggul.

Tabel 8. Hasil Analisis X-Model 5 Komoditas Ekspor Unggulan Indonesia ke Vietnam

\begin{tabular}{cllcl}
\hline $\begin{array}{c}\text { Kode } \\
\text { HS }\end{array}$ & Deskripsi Produk & Posisi EPD & $\begin{array}{c}\text { Rata-rata } \\
\text { RCA }\end{array}$ & $\begin{array}{c}\text { Ekspor Produk } \\
\text { Potensial }\end{array}$ \\
\hline 0307 & $\begin{array}{l}\text { Molluscs, whether in } \\
\text { shell or not, }\end{array}$ & Falling Star & 6.20 & $\begin{array}{l}\text { Pengembangan } \\
\text { pasar potensial }\end{array}$ \\
0801 & $\begin{array}{l}\text { Coconuts, Brazil nuts } \\
\text { and cashew nut }\end{array}$ & Falling Star & 5.76 & $\begin{array}{l}\text { Pengembangan } \\
\text { pasar potensial }\end{array}$ \\
1511 & $\begin{array}{l}\text { Palm oil and its } \\
\text { fractions, whether } \\
\text { Pepper of the genus }\end{array}$ & Falling Star & 15.73 & $\begin{array}{l}\text { Pengembangan } \\
\text { pasar potensial }\end{array}$ \\
0904 & $\begin{array}{l}\text { Piper; dried or } \\
\text { Bread, pastry, cakes, } \\
\text { biscuits and }\end{array}$ & Falling Star & 24.47 & $\begin{array}{l}\text { Pengembangan } \\
\text { pasar potensial }\end{array}$ \\
\hline
\end{tabular}

Sumber: WITS (diolah), 2020

Berdasarkan tabel 2.5 diketahui bahwa dari lima komoditas unggulan ekspor Indonesia ke Vietnam tahun 2010-2019 terdapat produk ekspor unggulan yaitu lada dengan membandingkan RCA dan EPD. Maka dari itu, pengembangan ekspor Indonesia ke Vietnam disarankan untuk mengembangkan produk ekspor unggulan yaitu lada. Hal ini dikarenakan komoditas tersebut adalah komoditas yang menjanjikan dan memiliki pengembangan pasar yang potensial, sehingga berdaya saing kuat dibandingkan keempat komoditas unggulan lainnya. Meskipun kelima komoditas unggulan berada pada posisi pasar falling star, masih dapat ditingkatkan di pasar Vietnam. 


\section{Hambatan Ekspor Indonesia ke Vietnam}

\section{Hambatan Tarif}

Indonesia dan Vietnam merupakan negara yang tergabung dalam AFTA (ASEAN Free Trade Area) yang merupakan perjanjian dagang dengan membebaskan penerapan tarif bagi negara sesama
ASEAN. Oleh sebab itu, diketahui bahwa penerapan tarif ekspor ke Vietnam dari tahun 2010-2019 bernilai 0 yang ditunjukkan dari nilai PRF pada tabel 9. Sedangkan untuk negara-negara pesaing lain yang merupakan anggota WTO, Vietnam menerapkan tarif perdagangan untuk komoditas lada sebesar $20 \%$ yang ditunjukkan dari nilai MFN.

Tabel 9. Tarif yang Dikenakan Vietnam pada Indonesia dan Negara WTO Tahun 2010-2019

\begin{tabular}{ccc}
\hline Jenis Tarif & Tahun & Besar Tarif $(\%)$ \\
\hline \multirow{3}{*}{ PRF } & 2012 & 0 \\
& 2013 & 0 \\
& 2014 & 0 \\
2015 & 0 \\
2016 & 0 \\
& 2018 & 0 \\
2019 & 0 \\
\hline MFN & 2010 & 20 \\
& 2012 & 20 \\
& 2013 & 20 \\
& 2014 & 20 \\
& 2015 & 20 \\
& 2016 & 20 \\
& 2017 & 20 \\
& 2018 & 20 \\
\hline
\end{tabular}

Sumber: WITS (2020)

Tidak diberlakukannya tarif dari Vietnam bagi Indonesia menjadi peluang bagi Indonesia untuk meningkatkan ekspor komoditas lada dalam upaya diversifikasi pasar ekspor ke negara non-tradisional. Oleh sebab itu, Indonesia sebaiknya mulai fokus pada peningkatan komoditas lada ke Vietnam, mengingat potensi dari tidak diberlakukannya tarif, serta potensipotensi keunggulan produk yang telah dijabarkan sebelumnya. Selain itu, perang dagang yang selama ini terjadi antara Amerika Serikat dan China telah berdampak cukup besar pada perdagangan Indonesia. Pasalnya, Amerika Serikat dan China merupakan dua negara tujuan ekspor yang paling utama Indonesia selama ini. Hal tersebut membuat diversifikasi ekspor ke negara tujuan lain, salah satunya Vietnam, semakin penting dan harus mulai menjadi fokus utama dalam kegiatan ekspor Indonesia. (Novianti, 2020).

\section{Hambatan non-Tarif}

Meskipun ekspor Indonesia ke Vietnam terbebas dari hambatan tarif, namun terdapat hambatan non-tarif yang diberlakukan Vietnam. Berdasarkan data WITS (2020), Indonesia menghadapi 640 instrumen hambatan non-tarif dalam ekspor lada ke Vietnam. Hasil perhitungan FI pada impor produk lada (0904) di Vietnam bernilai $100 \%$. Hal tersebut berarti bahwa $100 \%$ produk lada, baik mentah maupun produk turunan, pasti terkena setidaknya satu jenis NTM. Sehingga, ada hal-hal yang perlu diperhatikan Indonesia dalam ekspor produk lada ke Vietnam, yaitu: 
1. Batas toleransi untuk residu atau kontaminasi oleh zat (non-mikrobiologis) tertentu

Menurut Kamus Besar Bahasa Indonesia (KBBI), residu berarti ampas atau endapan. Residu pada komoditas pertanian dapat bersumber dari pestisida yang digunakan. Konsumsi produk pertanian yang mengandung residu pestisida dalam jangka panjang dapat mengganggu kesehatan. Oleh karena itu perlu adanya pengembangan pertanian ramah lingkungan guna meminimalisir tingkat kontaminasi. Selain itu, tuntutan dari negara tujuan ekspor produk- produk pertanian indonesia terkait Batas Minimum Residu Pestisida (BMR) yang rendah harus diperhatikan.

2. Persyaratan dalam pelabelan dan pengemasan

Persyaratan pelabelan mengatur mengenai jenis dan ukuran pencetakan pada kemasan dan label serta menentukan informasi yang mungkin atau harus diberikan kepada konsumen. Sedangkan persyaratan pengemasan mengatur cara di mana barang harus atau tidak dapat dikemas, sesuai dengan peralatan penanganan negara pengimpor atau karena alasan lain, dan menentukan bahan pengemas yang akan digunakan.

3. Persyaratan pengujian, sertifikasi, dan inspeksi

Produk ekspor wajib lulus uji dari laboratorium yang ditunjuk oleh negara pengimpor dalam hal ini Vietnam, pemeriksaan barang oleh otoritas kesehatan berwenang sebelum dikeluarkan dari pabean atau persyaratan karantina untuk hewan dan tumbuhan hidup.

4. Asal bahan baku dan suku cadang

\section{Regional Value Content (RVC)} merupakan persentase kandungan produk yang berasal dari negara asal (ASEAN). Perjanjian AFTA menetapkan batas minimal RVC sebesar $40 \%$, sehingga semua produk yang diekspor ke kawasan ASEAN minimal harus mengandung $40 \%$ produk asli negara tersebut.

5. Persyaratan produksi dan/atau pasca produksi

Persyaratan produksi dan pasca produksi mencakup semua prosedur yang terjadi baik selama proses produksi maupun pasca produksi, Berdasarkan kesepakatan AFTA, komoditas ekspor harus sepenuhnya diproduksi dari salah satu negara yang terlibat (Indonesia atau Vietnam)

6. Langkah-langkah ekspor terkait Sanitary and Phytosanitary Standards (SPS) dan Technical Barrier to Trade (TBT).

Kesepakatan mengenai SPS dan TBT memperkenalkan perlunya bagi negara anggota WTO untuk tidak hanya melindungi dari resiko yang disebabkan oleh masuknya hama, hewan dan tumbuhan tetapi juga harus meminimalisir dampak negatif dari proses karantina dan yang berkaitan dengan hal teknis. secara singkat SPS merupakan kebijakan atau pembatasan untuk melindungi manusia, hewan atau tumbuhan hidup seperti prosedur pengujian dan penanganan karantina. sedangkan TBT berkaitan dengan peraturan teknis lainnya, standar dan penilaian kesesuaian.

Dampak dari adanya hambatan non-tarif dalam ekspor komoditas lada Indonesia cukup besar, meskipun hanya berkaitan dengan Quality Control produk. Berdasarkan hasil perhitungan $\mathrm{CR}$, perdagangan Indonesia ke Vietnam memiliki nilai CR sebesar $100 \%$. Hal tersebut menunjukkan bahwa semua nilai produk lada yg Indonesia ekspor ke Vietnam terkena dampak NTM dan harus memenuhi syarat kriteria NTM di Vietnam. Oleh sebab itu, berdasarkan analisis FI dan CR bahwa pemerintah Indonesia harus memperhatikan aspek persyaratan-persyaratan ekspor ke Vietnam seperti meningkatkan Quality Control produk sebelum diekspor ke Vietnam.

\section{Potensi Pengembangan Ekspor Produk Lada ke Vietnam}

Peluang ekspor komoditas lada ke Vietnam memang sangat besar, mengingat potensi produk serta hambatan yang secara keseluruhan tidak begitu besar dan menyulitkan. Namun, terdapat negara pesaing yang juga mengekspor komoditas lada ke Vietnam. 
Tabel 10. Negara Pesaing Ekspor Lada ke Vietnam Tahun 2010-2019

\begin{tabular}{ccc}
\hline No. & Negara & $\begin{array}{c}\text { Total Nilai Ekspor (1000 USD) Tahun } \\
\mathbf{2 0 0 9 - 1 0 1 9}\end{array}$ \\
\hline 1 & India & $1,001,191,857$ \\
2 & Indonesia & $794,021,389$ \\
3 & Brazil & $128,802 ., 25$ \\
4 & Malaysia & $63,513,880$ \\
5 & Singapore & $58,183,207$ \\
6 & China & $54,612,893$ \\
\hline
\end{tabular}

Sumber : WITS (diolah), 2020

Tabel 10 menunjukkan bahwa total nilai ekspor Indonesia dari tahun 2009-2019 sejatinya Indonesia berpeluang besar dalam meningkatkan ekspornya. Hal tersebut karena posisi Indonesia yang berada di urutan ke-2 terbesar setelah India. Namun, hal tersebut juga menunjukkan bahwa Indonesia dalam hal ini masih belum unggul dalam negara pesaingnya yakni India, yang mana jika total nilai ekspor lada dari India ke Vietnam dibandingkan dengan total nilai ekspor lada dari Indonesia ke Vietnam memiliki perbedaan nilai sebesar 207,170,468. Indonesia pun dinilai berpeluang besar dalam meningkatkan ekspor disebabkan pada tabel di atas, total nilai ekspor lada Indonesia pada tahun 2009- 2019 berada pada posisi kedua dengan negara pesaing ekspor lada ke Vietnam adalah Brazil, Malaysia, Singapore, dan China. Maka dari itu, terbukti bahwa Indonesia memiliki pasar yang dominan pada komoditas lada di Vietnam jika dibandingkan dengan empat negara pesaing lainnya dan berpeluang besar dalam meningkatkan daya saing ekspor lada ke Vietnam agar dapat bersaing dengan negara India.

\section{SIMPULAN DAN SARAN}

\section{Simpulan}

Lada merupakan komoditas ekspor Indonesia yang paling unggul diantara komoditas pertanian lain. Berdasarkan hasil analisis ISP (Indeks Spesialisasi Perdagangan) antara perdagangan dari komoditas lada negara Indonesia dan Vietnam, negara Indonesia memiliki daya saing yang kuat terhadap komoditas lada atau berpotensi sebagai negara eksportir. Komoditas lada semakin berpotensi sebagai produk utama ekspor ke Vietnam ditunjukkan dari hasil analisis RCA. Hasil RCA dari ekspor komoditas lada ke Vietnam menunjukkan bahwa daya saing komoditas lada Indonesia memiliki daya saing yang kuat di pasar Vietnam, sehingga semakin menunjukkan bahwa komoditas lada memang komoditas yang sangat potensial untuk peningkatan kegiatan perdagangan Indonesia ke Vietnam. Selain itu, berdasarkan hasil analisis X-Model, pengembangan ekspor Indonesia ke Vietnam disarankan untuk mengembangkan produk ekspor unggulan yaitu lada. Hal ini dikarenakan komoditas tersebut adalah komoditas yang menjanjikan dan memiliki pengembangan pasar yang potensial, sehingga berdaya saing kuat dibandingkan keempat komoditas unggulan lainnya. Namun, potensi ekspor lada tersebut masih belumtermanfaatkan secara maksimal.

Berdasarkan hasil analisis IIT, integrasi perdagangan antara Indonesia dan Vietnam masih sangat lemah, meskipun sempat menguat pada tahun 2014. Integrasi yang lemah tersebut dikarenakan Vietnam bukan negara tujuan utama ekspor Indonesia atau termasuk kategori negara non-tradisional. Selain integrasi yang masih lemah, posisi ekspor komoditas lada Indonesia ke Vietnam pun masih perlu ditingkatkan. Pasalnya, posisi ekspor di Indonesia di pasar Vietnam sangat berfluktuasi setiap tahunnya cenderung kurang potensial. 
Berdasarkan hasil analisis EPD, daya saing komoditi lada Indonesia masih rendah jika dibandingkan dengan negara lain di pasar Vietnam. Selain karena faktor eksternal, ternyata masih kurang dimanfaatkannya ekspor lada ke Vietnam karena belum dimanfaatkannya sumber daya alam untuk mendukung produksi lada secara maksimal, sehingga produktivitas lada nasional masih tergolong rendah. Berkaitan dengan pengembangan potensi ekspor lada Indonesia ke Vietnam, Indonesia dan Vietnam merupakan negara yang tergabung dalam AFTA (ASEAN Free Trade Area) yang merupakan perjanjian dagang dengan membebaskan penerapan tarif bagi negara sesama ASEAN. Pembebasan tarif tersebut dapat menjadi peluang bagi Indonesia untuk meningkatkan ekspor komoditas lada dalam upaya diversifikasi pasar ekspor ke negara non-tradisional. Meskipun ekspor Indonesia ke Vietnam terbebas dari hambatan tarif, namun terdapat hambatan nontarif yang diberlakukan Vietnam. Berdasarkan hasil perhitungan FI, $100 \%$ produk ekspor lada dari Indonesia, baik mentah maupun produk turunan, pasti terkena setidaknya satu jenis NTM yang ditetapkan Vietnam.

\section{Saran}

Rendahnya nilai integrasi perdagangan Indonesia dengan Vietnam dikarenakan masingmasing negara memiliki keunggulan komparatif pada komoditas lada sehingga setiap negara mitra dagang bisa dikatakan tidak terlalu sering melakukan perdagangan intra-industri satu sama lain. Perdagangan intra industri yang rendah bisa menjadi sarana bagi pemerintah Indonesia untuk lebih memperhatikan komoditas produk lada bagi negara mitra dagang Indonesia lain diluar Vietnam, karena bisa dikatakan ekspor komoditas lada Indonesia termasuk unggul dalam pasar ASEAN maupun pasar dunia. Selain itu, cara yang dapat dilakukan pemerintah adalah menjalin kerja sama dengan berbagai negara dan organisasi dagang dunia untuk membuka pangsa pasar baru dalam upaya meningkatkan pangsa pasar Indonesia di perdagangan dunia. Bentuk kerja sama yang dilakukan pertama adalah dengan meningkatkan kualitas kerja sama dengan negara konsumen utama lada di dunia, salah satunya
Amerika Serikat. Namun, selain faktor eksternal terkait kerja sama perdagangan, perlu adanya upaya pembenahan internal yaitu dari dalam negeri. Adanya dorongan korporasi petani diperlukan untuk menguatkan kelembagaan petani lada. Petani-petani dapat membentuk kelompok. Dari kelompok tani menjadi gapoktan, dari gapoktan menjadi koperasi, sehingga bargaining position lebih tinggi. Harus lebih jeli apa yang di kerja samakan.

Indonesia menjadi pengekspor lada, salah satunya ke Vietnam, namun disisi lain Indonesia juga mengimpor lada. Maka penting penguatan kelembagaan atau inovasi-inovasi diversifikasi produk berbasis lada yang dapat diproduksi di Indonesia. Oleh karena itu pemerintah perlu berupaya melakukan pendampingan para petani untuk melakukan diversifikasi produk dan meningkatkan kualitas produk lada dan perbaikan budidaya serta pengembangan produk turunan lada untuk mendapatkan ragam, kualitas serta nilai tambah yang lebih baik. Selama ini Indonesia banyak melakukan ekspor butiran besar. Harapannya sektor perindustrian dapat membantu agar produk lada bernilai tinggi. Lebih lanjut lagi, untuk menghadapi hambatan yang diberlakukan oleh negara mitra dagang, terutama hambatan non-tarif, perlunya lebih memperhatikan dan memperketat pengawasan terhadap aspek Quality Control produk dalam menghadapi tantangan hambatan non-tarif ke Vietnam.

\section{DAFTAR PUSTAKA}

Aerisha, Y. 2017. Analisis komparasi daya saing ekspor lada Indonesia terhadap Vietnam dan Malaysia di pasar Asean. Skripsi. Universitas Jambi

Arzila. Indonesian Government Effort to Teach Vietnam in Exports of Pepper in The International Market. Jom Fisip. 6 Juli Desember 2019:1-14.

Azahari DH, Purba HJ, Darwis V, Dabukke FBM, Hestina J, Yusuf ES. 2021. The Competitiveness of Indonesia's Pepper Export and Its Challanges. IOP Conference Series Earth and Environmental Science. 892(1): 012074 
Balqis P., \& YanuarR. (2021). Daya Saing Ekspor Lada Indonesia di Pasar Amerika dan Eropa. Forum Agribisnis : Agribusiness Forum, 11(2), 182-194. https://doi.org/10.29244/fagb.11.2.182194

Jannah EM, Nurmalina R, Asmarantaka RW. 2019. Tingkat Persaingan Eksportir Utama Lada Dunia.

Jurnal Agro Industri Perkebunan. 7(2): 107120.

Jusuf R, Setyari NPW. 2020. Analisis Keunggulan Komparatif Ekspor lada Indonesia Tahun 2010-2016.

$J$ Bus Polit Rconomy. 2(1).

Kementerian Perdagangan. 2020. Neraca perdagangan Indonesia dengan Vietnam periode: 2016 - 2021 [Internet]. URL: https://statistik.kemendag.go.id/balanceof-trade-with-trade-partner-country [diakses tanggal 1 Juni 2021].

Kementerian Pertanian. 2019. Statistik ketenagakerjaan sektor pertanian (Agustus 2019). Jakarta: Pusat Data dan Sistem Informasi Pertanian Sekretariat Jenderal - Kementerian Pertanian 2019

Kurnianto DT, Suharyono, Mawardi H. 2016. Daya Saing Komoditas lada Indonesia di Pasar Internasional (studi tentang ekspor lada Indonesia tahun 2010-2014). Jurnal
Administrasi Bisnis.40(2): 58-64.

Novianti, T. 2020. Perang Dagang AS-China dan Dampaknya bagi Indonesia

Nurhayati, E., Hartoyo, S., \& Mulatsih, S. (2018). Pengembangan Pasar Ekspor Lada Indonesia. Buletin Ilmiah Litbang Perdagangan. 12(2):267-288. https://doi.org/10.30908/bilp.v12i2.335

Rusydiana AS. 2009. Hubungan Antara Perdagangan Internasional, Pertumbuhan Ekonomi dan Perkembangan Industri Keuangan Syariah di Indonesia. Jurnal TAKZIA Islamic Finance \& Bussines Review. 4(1): 47-60

Setiadi, E. 2016. Perjanjian ekstradisi antara Indonesia dan Vietnam. International \& Diplomacy. 2 (1):83-94

UN Comtrade. 2019. Komoditas Pertanian Unggulan Ekspor Indonesia-Vietnam [Internet]. [Diunduh tanggal $30 \mathrm{Mei}$ 2021].

UN Comtrade. 2019. Lima Negara Eksportir Lada Terbesar ke Vietnam Tahun 2019 [Internet]. [Diunduh tanggal $30 \mathrm{Mei}$ 2021].

Zuhdi Fadhian, Suharno. 2016. Analisis Daya Saing Ekspor Kopi Indonesia dan Vietnam di Pasar Asean. Habitat, 26 (03): 152-162. 